Doi: https://doi.org/10.31578/jebs.v6i1.218

\title{
Influence of Social Media on Students' Academic Performance as Perceived by Undergraduate Education Students
}

Fakokunde Jubril Busuyi *

\begin{abstract}
The use of social media among tertiary institution students has been the concern of scholars within the education realm in respect of the influence on academic performance. While some have found positive impact, others have recorded negative or neutral. However, specific attention has not been given education students who are the potential builders of up-coming generation on their views in relation to the influence on academic performance. This study therefore investigated the perceived influence of the use of social media on students' academic performance. The study adopted a descriptive survey design by randomly selecting 297 undergraduate education students of Osun State University from $2^{\text {nd }}, 3^{\text {rd }}$ and final year students. The instrument used for data collection is a self-developed questionnaire titled 'Influence of Social Media on Academic Performance'. One research question and two hypotheses were generated for the study. Data were analysed using simple percentage and frequency count aspect of descriptive statistics, $\mathrm{t}$-test and Analysis of Variance (ANOVA). The results showed that the use of social media has both positive and negative influence on academic performance. The study also revealed no bias in the view of the respondents based on gender and number of years spent as students in the university. The researcher therefore recommends the need to educate students on the educational benefits of social media, guide the students on how to use social media to enhance learning coupled with the incorporation of social media as instructional strategy in the school curriculum.
\end{abstract}

Keywords: Academic performance, perception, social media, undergraduate students

\section{Introduction}

The coming into existence of social networking sites as an offshoot of the advancement in information and communication technology has further promoted the transformation of the whole world into a global village in terms of information transmission and accessibility. The use of social media such as Facebook, Whatsapp, 2go, Myspace, YouTube, Blogs, Twitter amongst others for quick dissemination of information and instant response when the need arises has removed the dependency on traditional information dissemination media such as radio, television and newspaper. Social media according to Carr (2019) are website and applications that enable users to create and share content or participate in social networking. According to Cooper (2019), the use of social networking sites by students in higher institutions precedes their admission into higher institution as they use them in searching for higher institutions intended to be attended by prospective international students into United Kingdom. The scholar admits social media as a prominent means of acquiring and disseminating information by young people with emphasis on the use of facebook, YouTube, Istagram, Linkedln and Pinterest.

* Department Science, Technology and Mathematics Education, Osun State University, Ipetu-ljesa Campus, Osun State, Nigeria. 
Social media has become part of the individual's daily life as a primary channel for communication and social interaction. Social media use is relevant in the realm of education as relevant learning resources such as pictures, photos, assignments, videos and announcement on academic issues can be communicated to students through them. The study of Tayo, Adebola and Yahya (2019) reveals undergraduate students' use of social media for socialization, information and academic. Social media allow students to engage in online group discussion thereby facilitating teaching-learning activities beyond the four walls of the classroom environment.

In the view of Jeffrey and Musah (2015), social media has permeated all aspects of our society with both positive and negative effects. The scholars posit that social media have transformed and impacted on communication, learning, research and education in general. Scholars such as Boateng and Amankaa (2016), Kolan and Dzandza (2018), and Tayo et al, (2019) have attested to the prevalence of the use of social media among university undergraduate students for both academic and non academic purposes as majority of them spent between one to three hours daily on social networking sites.

The use of social media among Nigerian students has been attested to by scholars. Amadi and Ewa (2018) while investigating the use of social media by undergraduate students in River State, University, Port Harcourt, Nigeria assert the use of social media by the students at an average of six hours per day. This commitment to the use of social media by undergraduate students has also been affirmed by Tayo et al (2019) based on the revelation that undergraduate students in Obafemi Awolowo University, Ile-Ife, Nigeria spend an average of 2-3 hours on social media on daily basis. The above attest to the finding of Adewale (2011) cited in Unwachuku and Emenike (2016).

The excessive commitment of Nigerian students and youths to social media has continued to be of great concern to stake holders within the education realm. Omoyele (2016) while examining poor reading habit among Nigerian students identifies students' commitment to social media such as Whatsapp, Facebook among others as contributory factor. Fori (2016) citing Onoyase (2014) attributes many deviant noticeable behaviour such as deliberate lateness to lectures, absenteeism, inattentiveness in class, unwillingness to acquire necessary materials for academic pursuit and engaging excessively on un-educative activities on social media by undergraduate students in Delta State University, Nigeria as contributory factors to poor academic performance. Nwazor and Godwin-Maduike (2015) assert that students' commitment to social media leads to decrease in productivity, poor grammar usage, reduction in research capabilities, involvement in frivolities and reduction in interpersonal relation which are detrimental to their academic endeavour. The negative influence of social media has also been attested to by Ameyaw, Asante and Asante (2017), and Araoye (2018).

In spite of the aforementioned negative effects of social media on academic performance, studies have also revealed positive and neutral effects of the use among students. Adam and Ab-Rahim (2014) admit positive effects of the use on social media on students' academic performance based on the opportunities accorded the students to communicate with faculty and university authorities, lecturers, supervisors, discuss academic topics with classmates and chat with friends on topics of educational interest. Hadebe, Owolabi and Mlambo (2016), and Fatokun (2019) reveal positive effect of the use of social media on the academic performance of undergraduate students. However, Camilia, Ibrahim and Dalhatu (2013), Fori (2016), Sani, Amosa and Zubairu (2016) find no significant effect of social media usage on students' academic performance among tertiary institution students..

The use of social media and the perceived influence could be determined by variable such as gender and number of years spent in the university. Gender has been found to be one of the important variables in Nigeria and other African countries due to the role attributed and expected of male and female. This role expectation could influence the commitment and disposition of students of different gender to the use and perception of social media. Rollero, Daniele and Tartaglia (2019) reveal that men are 
more committed to the use of social media than women which could be attributed to their perception on the influence of social media on their academic performance. This finding goes in line with Misra, Dangi and Patel (2015) and Alnjadat, Hmaidi, Samha, Kilani and Hasswan (2019). In the finding of Amadi and Ewa (2018), there is divergence between male and female university students on their use of social media. The study shows that while males use social media mainly for information and academic, females are committed to the use for socialization and entertainment.

The number of years a student has spent in a university could also influence the use of social media and the perceived influence on academic performance. Students' activities in schools could be influenced by the number of years spent in the school. A newly admitted student to a four year programme cannot act within the school environment like those who have spent between two to three years in the school as familiarity with the school rules and regulations, understanding of the loopholes in the rules and regulations coupled with proper understanding of the school environment cannot be at par. This postulation has been attested to by Sutherland, Davis, Terton and Visser (2018). The scholars find that students in the later years of their undergraduate programme are more committed in using social media in their interaction with the university community. Premised on the above, the perception of university students on the influence of social media on their academic performance could be influence by the number of years spent in the university.

The inconsistence in the views of scholars on the influence of social media on students' academic performance coupled with lack of specific study focusing on education students with gender and number of years spent in the university as moderator variables necessitate this study.

\section{Statement of the Problem}

The surge in the use of social media among university undergraduate students for both academic and non academic purposes cannot be underestimated based on the accessibility of different social media sites via the internet coupled with nearly unrestricted access to disseminate and retrieve information at virtually zero cost. Undergraduate students have been found of placing premium on the use of social media in their daily activities which could impact negatively on their academic performance thereby making it a point of concern to government, parents, teachers and other stake holders both within and outside the education system due to decline in students' performance.

Scholars in the field of education have tried to investigate the influence of social media on academic performance but their findings continue to be inconsistent. While some have attributed students' poor academic performance to excessive commitment to the use of social media for non-academic activities, some have found positive influence of the use on academic performance while others did not find significant correlation in undergraduate students' use of social media and their academic performance. This divergence in the findings could be attributed to the difference in the locations where the studies are carried out and the variables involved in the study of different scholars.

This inconsistence in the findings requires further studies on the topical issue. So also, due consideration has not been given to investigating the views of education students whose knowledge of the influence could help in shaping the up-coming generation that they are to mentor as teachers.

This study therefore investigated the influence of social media on academic performance premised on the views of undergraduate education students. 


\section{Research Question}

1. What is the influence of social media usage on students' academic performance as perceived by university undergraduate education students?

\section{Hypotheses}

1. There is no significant influence of gender on undergraduate education students' perception of the influence of social media on academic performance.

2. There is no significant influence of number of years spent in the university on undergraduate education students' perception of the influence of social media on academic performance.

\section{Methodology}

The study adopted a descriptive survey research design involving the selection of some respondents from the population in order to assess their opinions as the general view of the entire population. The research design adopted is suitable because none of the variables in the study was manipulated. The population consisted all education students in Osun State University who have spent at least an academic session within the university system. A sum 300 students were randomly selected out of a population of about 1000 students from those in $2^{\text {nd }}, 3^{\text {rd }}$ and final years. The choice of the students rests on the need to select respondents that are familiar with the university system. It focuses the hypothesis and research questions in the study with due consideration of existing literature on both the negative and positive influence of social media on students' academic performance. The research instrument is a self-developed questionnaire titled 'Influence of Social Media on Academic Performance'. It was based on the literature review above. The questionnaire was divided into two sections made up of the demographic information of the participants in terms of gender and number of years spent in the university and a list 20 items relating to the research question and hypotheses placed on a Likert scale of strongly agree (SD) agree (A), disagree (D) and strongly (SD). The initial draft of the instrument was given to two lecturers in the field of educational technology to assess its appropriateness for the study. Their observations and suggestions were used as a guide in the final draft of the instrument. The research instrument was administered to 25 students from another institution not included in the study, but shared the same characteristics with the participants in the study. Their responses were analysed using split-half technique and a reliability coefficient of 0.78 was obtained. The research instrument was administered to 300 education students out of which 297 were retrieved. Simple percentage and frequency count aspects of descriptive statistic were used to analyse the data to answer the research question while t-test and Analysis of Variance (ANOVA) were used to test hypotheses I and 2 respectively.

Table 1. Reliability Coefficient Table

\begin{tabular}{|c|c|c|}
\hline$S / N$ & $X$ & $Y$ \\
\hline 1 & 43 & 41 \\
\hline 2 & 62 & 61 \\
\hline 3 & 61 & 51 \\
\hline 4 & 52 & 59 \\
\hline 5 & 52 & 49 \\
\hline 6 & 63 & 60 \\
\hline
\end{tabular}




\begin{tabular}{|c|c|c|}
\hline 7 & 55 & 47 \\
\hline 8 & 39 & 33 \\
\hline 9 & 46 & 51 \\
\hline 10 & 55 & 51 \\
\hline 11 & 51 & 50 \\
\hline 12 & 50 & 55 \\
\hline 13 & 47 & 45 \\
\hline 14 & 65 & 57 \\
\hline 15 & 49 & 50 \\
\hline 16 & 52 & 57 \\
\hline 17 & 51 & 53 \\
\hline 18 & 39 & 35 \\
\hline 19 & 49 & 51 \\
\hline 20 & 54 & 50 \\
\hline 21 & 47 & 49 \\
\hline 22 & 47 & 46 \\
\hline 23 & 42 & 47 \\
\hline 24 & 52 & 53 \\
\hline 25 & 49 & 50 \\
\hline \multicolumn{2}{|c|}{$\begin{array}{l}\text { Reliability Coefficient } \\
\text { (Cronbach's alpha) }\end{array}$} & 0.78 \\
\hline
\end{tabular}

\section{Results}

Table 2: Gender Distribution of the Respondents

$(\mathrm{N}=297)$

\begin{tabular}{|c|c|c|}
\hline & $\mathrm{F}$ & $\%$ \\
\hline Male & 134 & 45.1 \\
\hline Female & 163 & 54.9 \\
\hline Total & 297 & 100.0 \\
\hline
\end{tabular}

Table 2 shows that $45.1 \%$ of the respondents is male while $54.9 \%$ is female implying adequate representation of both male and female participants in the study.

Table 3: Distribution of the Respondents According to their Years of Study

$$
\text { ( } N=297)
$$

\begin{tabular}{|c|c|c|}
\hline Level & $\mathrm{F}$ & $\%$ \\
\hline 200 & 102 & 34.3 \\
\hline 300 & 127 & 42.8 \\
\hline
\end{tabular}




\begin{tabular}{|c|c|c|}
\hline 400 & 68 & 22.9 \\
\hline Total & 297 & 100.0 \\
\hline
\end{tabular}

Table 3 presents the distribution of the respondents according to their years of studying in the university. It shows that $34.3 \%$, $42.8 \%$ and $22.9 \%$ of the students are in $2^{\text {nd }}, 3^{\text {rd }}$ and $4^{\text {th }}$ years in the university respectively.

Research Question: What is the influence of social media usage on students' academic performance as perceived by university undergraduate education students?

Table 4: Analysis of Perceived Influence of Social Media on Academic Performance by Undergraduate Education Students (N = 297)

\begin{tabular}{|c|c|c|c|c|c|}
\hline \multirow[t]{2}{*}{$\mathrm{S} / \mathrm{N}$} & \multirow[t]{2}{*}{ ITEM } & \multicolumn{4}{|c|}{ Responses } \\
\hline & & SD & $\mathrm{D}$ & A & SA \\
\hline 1 & Social media reduce students' commitment to academic activities & $\begin{array}{l}16 \\
(5.4)\end{array}$ & $\begin{array}{l}38 \\
(12.8)\end{array}$ & $\begin{array}{c}97 \\
(32.7)\end{array}$ & $\begin{array}{l}146 \\
(49.2)\end{array}$ \\
\hline 2 & $\begin{array}{l}\text { A lot of time is wasted by students through interaction on social } \\
\text { media }\end{array}$ & $\begin{array}{l}17 \\
(5.7)\end{array}$ & $\begin{array}{l}38 \\
(12.8)\end{array}$ & $\begin{array}{l}113 \\
(38.0)\end{array}$ & $\begin{array}{l}129 \\
(43.4)\end{array}$ \\
\hline 3 & $\begin{array}{l}\text { Social media have negative influence on students ' grammatical } \\
\text { expression }\end{array}$ & $\begin{array}{l}17 \\
(5.7)\end{array}$ & $\begin{array}{l}59 \\
(19.9)\end{array}$ & $\begin{array}{l}102 \\
(34.3)\end{array}$ & $\begin{array}{l}119 \\
(40.1)\end{array}$ \\
\hline 4 & $\begin{array}{l}\text { Students ' research work has been limited to the internet based on } \\
\text { the use of social media }\end{array}$ & $\begin{array}{l}18 \\
(6.1)\end{array}$ & $\begin{array}{l}49 \\
(16.5)\end{array}$ & $\begin{array}{l}124 \\
(41.8)\end{array}$ & $\begin{array}{l}106 \\
(35.7)\end{array}$ \\
\hline 5 & $\begin{array}{l}\text { The use of social media increases spelling errors in students' written } \\
\text { work }\end{array}$ & $\begin{array}{l}33 \\
(11.1)\end{array}$ & $\begin{array}{ll}54 \\
(18.2)\end{array}$ & $\begin{array}{l}104 \\
(35.0)\end{array}$ & $\begin{array}{l}106 \\
(35.7)\end{array}$ \\
\hline 6 & $\begin{array}{l}\text { The use of pidgin English by students has increased due to students' } \\
\text { commitment to social media }\end{array}$ & $\begin{array}{l}29 \\
(9.8)\end{array}$ & $\begin{array}{l}60 \\
(20.2)\end{array}$ & $\begin{array}{l}101 \\
(34.0)\end{array}$ & $\begin{array}{l}107 \\
(36.0)\end{array}$ \\
\hline 7 & Social media allow students to express their views on social issues & $\begin{array}{l}10 \\
(3.4)\end{array}$ & $\begin{array}{ll}35 \\
(11.8) \\
\end{array}$ & $\begin{array}{l}118 \\
(39.7) \\
\end{array}$ & $\begin{array}{l}134 \\
(45.1) \\
\end{array}$ \\
\hline 8 & $\begin{array}{l}\text { Social media allow students to discuss academic issue beyond the } \\
\text { classroom environment }\end{array}$ & $\begin{array}{l}8 \\
(2.7)\end{array}$ & $\begin{array}{l}29 \\
(9.8) \\
\end{array}$ & $\begin{array}{l}115 \\
(38.7) \\
\end{array}$ & $\begin{array}{l}145 \\
(48.8) \\
\end{array}$ \\
\hline 9 & $\begin{array}{l}\text { Social media facilitate quick dissemination of information among } \\
\text { students }\end{array}$ & $\begin{array}{l}7 \\
(2.4)\end{array}$ & $\begin{array}{l}23 \\
(7.7)\end{array}$ & $\begin{array}{l}94 \\
(31.6)\end{array}$ & $\begin{array}{l}173 \\
(58.2)\end{array}$ \\
\hline 10 & Social media promote collaborative work among students & $\begin{array}{l}9 \\
(3.0) \\
\end{array}$ & $\begin{array}{l}25 \\
(8.4) \\
\end{array}$ & $\begin{array}{l}121 \\
(40.7) \\
\end{array}$ & $\begin{array}{l}142 \\
(47.8) \\
\end{array}$ \\
\hline 11 & $\begin{array}{l}\text { The use of social media reduces interpersonal relation among } \\
\text { students }\end{array}$ & $\begin{array}{l}41 \\
(13.8)\end{array}$ & $\begin{array}{l}95 \\
(32.0) \\
\end{array}$ & $\begin{array}{l}100 \\
(33.7)\end{array}$ & $\begin{array}{l}61 \\
(20.5) \\
\end{array}$ \\
\hline 12 & $\begin{array}{l}\text { Social media allow for easy sharing of learning materials among } \\
\text { students }\end{array}$ & $\begin{array}{l}16 \\
(5.4)\end{array}$ & $\begin{array}{l}35 \\
(11.8)\end{array}$ & $\begin{array}{l}116 \\
(39.1)\end{array}$ & $\begin{array}{l}130 \\
(43.8)\end{array}$ \\
\hline 13 & $\begin{array}{l}\text { Social media encourage laziness on the part of some students as } \\
\text { they rely mainly on information from other students in doing their } \\
\text { academic work }\end{array}$ & $\begin{array}{l}(20) \\
(6.7)\end{array}$ & $\begin{array}{l}50 \\
(16.8)\end{array}$ & $\begin{array}{l}108 \\
(36.4)\end{array}$ & $\begin{array}{l}119 \\
(40.1)\end{array}$ \\
\hline 14 & $\begin{array}{l}\text { Group platforms formed by students on social media facilitate } \\
\text { interaction among them }\end{array}$ & $\begin{array}{c}4 \\
(1.3)\end{array}$ & $\begin{array}{l}33 \\
(11.1)\end{array}$ & $\begin{array}{l}99 \\
(33.3)\end{array}$ & $\begin{array}{l}161 \\
(54.2)\end{array}$ \\
\hline 15 & $\begin{array}{l}\text { A lot of students use social media to engage in activities that are } \\
\text { not relevant to their academic progress }\end{array}$ & $\begin{array}{l}22 \\
(7.4)\end{array}$ & $\begin{array}{ll}41 \\
(13.8)\end{array}$ & $\begin{array}{l}106 \\
(35.7)\end{array}$ & $\begin{array}{l}128 \\
(43.1) \\
\end{array}$ \\
\hline 16 & $\begin{array}{l}\text { Writing on social media platforms encourages students to write } \\
\text { than writing on paper }\end{array}$ & $\begin{array}{l}35 \\
(11.8)\end{array}$ & $\begin{array}{l}74 \\
(24.9)\end{array}$ & $\begin{array}{l}110 \\
(37.0)\end{array}$ & $\begin{array}{l}78 \\
(26.3)\end{array}$ \\
\hline 17 & $\begin{array}{l}\text { Social media assist in broadening students' knowledge on difficult } \\
\text { subject matter }\end{array}$ & $\begin{array}{l}11 \\
(3.7) \\
\end{array}$ & $\begin{array}{l}39 \\
(13.1) \\
\end{array}$ & $\begin{array}{l}137 \\
(46.1)\end{array}$ & $\begin{array}{l}110 \\
(37.0) \\
\end{array}$ \\
\hline 18 & $\begin{array}{l}\text { Social media encourage socialization among students rather than } \\
\text { enhancing academic performance }\end{array}$ & $\begin{array}{l}18 \\
(6.1)\end{array}$ & $\begin{array}{l}56 \\
(18.9)\end{array}$ & $\begin{array}{l}115 \\
(38.7)\end{array}$ & $\begin{array}{l}108 \\
(36.4)\end{array}$ \\
\hline
\end{tabular}




\begin{tabular}{|l|l|l|l|l|l|}
\hline 19 & Social media promote illicit activities among students & $\begin{array}{l}18 \\
(6.1)\end{array}$ & $\begin{array}{l}61 \\
(20.5)\end{array}$ & $\begin{array}{l}134 \\
(45.1)\end{array}$ & $\begin{array}{l}84 \\
(28.3)\end{array}$ \\
\hline 20 & $\begin{array}{l}\text { Social media constitute a distraction to students' academic } \\
\text { programme }\end{array}$ & 28 & 49 & 127 & 93 \\
& $(9.4)$ & $(16.5)$ & $(42.8)$ & $(31.3)$ \\
\hline
\end{tabular}

Table 4 presents the analysis of the perceived influence of social media on academic performance by undergraduate education students. The students agreed that: social media reduce students' commitment to academic activities (81.9\%); a lot of time is wasted by students through interaction on social media (81.4); social media have negative influence on students' grammatical expression (74.4\%); students' research work has been limited to the internet based on the use of social media (77.5\%); the use of social media increases spelling errors in students' written work $(70.7 \%)$; the use of pidgin English by students has increased due to their commitment to social media (70\%); social media allow students to express their views on social issues (84.8\%); social media allow students to discuss academic issues beyond the classroom environment (87.5\%); social media facilitate quick dissemination of information among students (89.8\%); social media promote collaborative work among students (88.5\%); The use of social media reduces interpersonal relation among students (54.2\%); social media allow for easy sharing of learning materials among students (82.9\%); social media encourage laziness on the part of some students as they rely mainly on information from other students in doing their academic work (76.5\%); group platforms formed by students on social media facilitate interaction among them (87.5\%); a lot of students use social media to engage in activities that are not relevant to their academic progress (78.8\%); writing on social media platforms helps in improving students' ability to write than writing on paper (63.3\%); social media assist in broadening students' knowledge on difficult subject matter (83.1\%); social media encourage socialization rather than enhancing academic performance (75.1\%); social media promote illicit activities among students (73.4\%); social media constitute a distraction to students' academic programme (74.1\%).

It can be inferred from the table that the use of social media has both positive and negative influence on students' academic performance.

Hypothesis 1: There is no significant influence of gender on undergraduate education students' perception of the influence of social media on academic performance

Table 5: Summary of t-test Analysis of Undergraduate Students' Perception of the Influence of Social Media on Students' Academic Performance based on Gender

\begin{tabular}{|c|c|c|c|c|c|c|c|}
\hline Sex & $\mathrm{N}$ & Mean & S.D & $\mathrm{T}$ & Df & Sig.(2 tailed) & Remark \\
\hline MALE & 134 & 62.30 & 6.57 & 0.005 & 295 & 0.996 & Not significant \\
\hline FEMALE & 163 & 62.29 & 6.96 & & & & \\
\hline
\end{tabular}

Table 5 shows that there is no significant influence of gender on undergraduate students' perception of the influence of social media on students' academic performane $(t=0.005, d f=295, p>0.05)$. Therefore, the null hypothesis is accepted.

Hypothesis 2: There is no significant influence of number of years spent in the university on undergraduate education students' perception of the influence of social media on academic performance. 
Table 6: Summary of ANOVA showing Undergraduate Education Students' Perception of the Influence of Social Media on Students Academic Performance Based on Years of Study in the University.

\begin{tabular}{|l|l|l|l|l|l|}
\hline & Sum of Squares & Df & Mean Square & F & Sig. \\
\hline Between Groups & 126.137 & 2 & 63.069 & \multirow{2}{*}{1.375} & \multirow{2}{*}{0.255} \\
\cline { 1 - 3 } Within Groups & 13487.789 & 294 & 45.877 & & \\
\cline { 1 - 3 } Total & 13613.926 & 296 & & & \\
\hline
\end{tabular}

A one-way ANOVA was conducted to examine if the undergraduate students' perception of the influence of social media on students' academic performance differ based on years of study in the university. The result reveals that there is no significant difference in the perception of undergraduate students on the influence of social media on academic performance based on years of study in the university $(F(2,294)=1.375, p=0.255)$. Since the $p$ value is greater than 0.05 , the null hypothesis is accepted.

\section{Discussion}

The study revealed both negative and positive influence of social media on academic performance premised on the perception of undergraduate education students. Problems associated with the use of social media include student undue commitment to the use for non-academic purposes, poor grammatical construction which could be linked to the use of unacceptable abbreviations, poor research activities among others while the positive influence entails collaboration among students beyond the classroom environment, quick dissemination of information among students to mention a few. The negative perception goes in line with the findings of Nwazor and Godwin-Maduike (2015) that attributed poor grammar usage, low research capabilities and involvement of students in unproductive ventures to their use of social media which have also been corroborated by Ameyaw, Asante and Asante (2017) and Araoye (2019) while the positive perception corroborates Adam and Ab-Rahim (2014), Hadebe, Owolabi and Mlambo (2016) and Fatokun (2019). However, the findings contradict Camilia, Ibrahim and Dalhatu (2013), Fori (2016) and, Sani, Amosa and Sulaiman (2016) which found no significant influence of social media usage on students' academic performance. The above finding could be attributed to the ability of the respondents to critically examine how social media influence academic performance. It further revealed that social media can advance or mar academic performance depending on the way and the purposes for which they are used.

The study also revealed that there is no significant difference in the perception of undergraduate education students on the influence of social media on academic performance based on gender. This implies that both male and female students are of the view that the use of social media can promote or hinder academic performance. Though studies such as those of, Misra, Dangi and Patel (2015); Rollero, Daniele and Tartaglia (2019) and Alnjadat, Hmaidi, Samha, Kilani and Hasswan (2019) revealed the commitment of male students to the use of social media than female students while Amadi and Ewa (2018) revealed divergence in the use, the result obtain in this study showed no difference in the perception of the use. This could be attributed to the fact that difference in the level of commitment and use do not prevent the students from critically assessing the positive and negative influence of the use on academic performance.

The study further showed that the perception of the respondents pertaining to the influence of the use of social media on students' academic performance based on the number of years spent in the university does not differ. They all viewed the use of social media as having both positive and negative influence on students' academic performance. Though, Sutherland, Davis, Terton and Visser (2018) found that students in the later years of undergraduate are more inclined to using social media in their interaction with the university community. However, this study showed that the number of years spent in the university does not 
influence their perception of the influence of social media on academic performance even, if the commitment to the use differs based on the number of years spent in the university.

\section{Conclusion}

The study investigated the perception of university undergraduate education students on the influence of the use of social media on academic performance of students. 297 respondents randomly selected from $2^{\text {nd }}, 3^{\text {rd }}$ and final year students of Osun State University participated in the study. The results obtained revealed that the respondents agreed that the use of social media by undergraduate students has both positive and negative influence on students' academic performance without bias on the platform of gender and years of study in the university. The respondents further agreed that social media usage promotes collaboration among students and allow learning to go beyond the school environment. However, the respondents also posited that social media reduce students' commitment to their academic thereby leading to poor academic performance. Thus, it is a wrong approach to totally avoid / ban the usage of social media, vice versa, it is important to treat its impact discriminatively support and develop it when necessary and limit its harmful applications. These findings overcome the earlier existing contradictions and enable teachers to reasonably apply social media in teaching.

\section{Recommendations}

The following recommendations are made based on the findings

1. Students should be enlightened on the educational benefits of social media so as to embrace the use in advancing their academic performance.

2. Students should be guided on how they can use social media to their educational advantage.

3. Since the commitment of the students to the use of social media has been ascertained, curriculum planners should look into how social media as a learning strategy can be incorporated into the school curriculum. 


\section{References}

Adam, M.H. \& Ab-Rahim, N.Z. (2014). The influence of social networking sites on students' academic performance in Malaysia. International Journal of Electronic Commerce. 5(2), 247-254.

Alnjadat, R., Hmaidi, M.M., Samha, T.E., Kilani, M.M. \& Hasswan, A.M. (2019). Gender variation in social media usage and academic performance among the students of University of Sharjah. Journal of Taibah University Medical Sciences, 14 (4), 390-394.

Amadi, E.C. \&Ewa, C.J. (2018). Social media and the academic performance of university students in Nigeria: A study of River State University, Port Harcourt. International Journal of Innovative Education Research, 6 (1), 23-29.

Ameyaw, S., Asante, A. E. \& Asante, E, (2017). Gender difference in social networking sites usage among students: Evidence from Koforidua Technical University, Ghana. IJRDO - J Journal of Social Science and Humanities Research. 2 (10), 1-21.

Araoye, O.I. (2018). Effect of social media on students' academic performance in higher institutions of learning in Nigeria. International Journal of Advanced Engineering and Science 3 (3), 58-62.

Boateng, R.A. \& Amankaa, A. (2016). The impact of social media on student academic life in higher education. Global Journal of Human-Social Science: Linguistic and Education, 16 (4), 1-7.

Carr. J. (2019). Social Media Compliance Policy. Retrieved from

https://www.liverpool.ac.uk/media/livacukcomputigservices/regulations/social-media-

policy.pdf

Camilia, O.N., Ibrahim, S.D. \& Dalhatu, B.L (2013). The effect of social networking site usage on the studies of Nigerian students. The International Journal of Engineering and Science (IJES). 2(7), 39-46.

Cooper, J. (2019). How international students use social media to choose a UK university. Retrieved from https://www.timeshighereducation.com/student/blogs/how-international-students-use-social-media-choose-ukuniversity.

Fatokun, K.V. (2019). Effect of social media on undergraduate students' achievement and interest in chemistry in the North-Central geo-political zone in Nigeria. International Journal of Science and Technology Education Research. 10 (2), 9-15.

Fori, E. (2016). Effect of social networking sites on the University of Maidugiri, Borno State,

Nigeria. International Journal of Computer Science Issues. 13(1), 76-84.

Hadebe, Z., Owolabi, Y. \& Mlambo, E. (2016). Use of social networking sites by undergraduate students in two African universities. Qualitative and Quantitative Methods in Libraries (QQML), 5, 743-749.

Jeffrey, M. \& Musah, A. (2015). Social media network participation and academic performanceinsenior high schools in Ghana. Library Philosophy and Practice (e-journal). Retrieved from http;//digitalcommons.unl.edu/libphi/prac/1286

Kolan, B.J \& Dzandza, P.E. (2018). Effect of social media on academic performance of students in Ghanian universities: A case study of University of Ghana, Legon. Retrieved from https://digitalcommons.unl.edu/cgi/viewcontent.cgi?article=4687\&content=libphilprac

Misra, N., Dangi, S. \& Patel, S. (2015). Gender differences in usage of social networking sites and perceived online social support on psychological wellbeing of youth. The International Journal of Indian Psychology, 3 (1), 63-74. 
Nwazor, J.C \& Godwin-Mduike, C.C (2015). Social media and academic performance of business education students in South-East Nigeria. Journal of Education and Practice. 6 (25), 127-134.

Omoyele, O. G. (2016). Nigerian students and poor reading habit. Retrieved from http://ondotv.com.ng/2016/03/16/nigeriastudents-and-poor-habit.

Rollero, C., Daniele, A. \&Tartaglia, S. (2019). Do men post and women view? The role of gender, personality and emotion in online social activity. Retrieved from https://cyberpsychology.eu/article/view/11564/10364.

Sani, A.A., Amosa, I. \&Zubairu, S.A. (2016). Relationship between social media utilization and achievement of undergraduate students in North-Western Nigeria. ATBU, Journal of Science, Technology and Education (JOSTE). 4 (3), 177-195.

Sutherland, K., Davis, C., Terton, U. \& Visser, I. (2018). University student social media use and its influence on offline engagement in higher educational communities. Student Success, 9 (2), 13-24.

Tayo, S.S., Adebola, S.T. \& Yahya, D.O. (2019). Social media usage and influence on undergraduate studies in Nigerian university. International Journal of Education and Development Using Information and Communication Technology (IJEDDICT), $15(3), 53-62$ 